\title{
Public Event: Global Communication M.A. Double Degree Program Colloquium Presentation - Part I: "My story, my research"
}

\author{
Sponsored by \\ Global Communication M.A. Double Degree Program
}

February 25, 2016 from 9:30am to 11:30am at SFU Vancouver Harbour Center Campus Room 2250

Dr. Xing Zeng is presenting Part I of the CMNS Double Degree Colloquium titled "My story, my research," on February 25, 2016 from 9:30am to 11:30am at SFU Vancouver Harbour Center Campus Room 2250. Light refreshments will be provided. Limited seats. First come, first served.

Using institutional ethnography Dr. Xing will analyze the relation between her positionality and her research in the context of contemporary China, and will comment on approaches to Communication research in her homeland. Having focused on empirical studies of media usage and social capital in her previous work on community media, Dr. Xing is now exploring post-positivist methods including standpoint theory.

Dr. Xing Zeng, Associate Professor, School of Journalism, Communication University of China, Beijing. Visiting Scholar 2015-16, Double MA in Global Communication, School of Communication, SFU.

Dr. Xing Zeng's research focuses on community media and comparative research methodologies. She earned her PhD at the Communication University of China. 